\title{
HIGHLIGHT
}

\section{CD154 for the dragon: a promising development for pancreatic islet transplantation and cure for type 1 diabetes mellitus}

\author{
Mehboob A Hussain \\ Laboratory of Molecular Endocrinology, Howard Hughes Medical Institute, 50 Blossom Street, Massachusetts General Hospital, Boston, \\ Massachusetts 02114, USA
}

Zeus looked down from the top of Mount Olympus and laid his eyes on Thurma, the beautiful princess of the small island kingdom of Styconos in the Aegean Sea. Smitten with desire, he instantly transformed himself into a white dove and flew down to win her affections. Thurma, delighted and utterly charmed by the sweet bird, easily succumbed to the god and soon thereafter found herself pregnant with a child. Hera, Zeus' sister and first wife had been watching, and, in her jealousy, had turned the son into a dragon while he was still in the womb of his mother. In her rage, Hera devised that the monster would grow evil and turn against the people of the kingdom. Meanwhile the King had received an oracle prophesying that his kingdom would be devastated by a dragon born from his daughter. Upon finding her pregnant, he immediately banished her to an isolated cave at the edge of the island, forbidding her to return until she had given birth and all was declared safe. Though she was visited daily by a royal attendant, Thurma was quite lonely in the dim light of the grotto, and spent countless hours singing to herself and her child. She sang of the pleasantries of the outside world, which she missed, as well as of the follies of famous heroes, and so, when her son was finally born among the shadows, while still dragon in form, his mind and spirit were gentle. Such was the King's despair at birth of the first dragon prince - seeing the fulfilment of the oracle - he abandoned Styconos and left with the disheartened Queen on a rough sea never to return. But Thurma loved her childdragon Hesperon (whose name means the son of a god and a beautiful princess), who at birth was so beautiful and gentle that the people of the island took him into their hearts. Even jealous Hera, who had come to see the fate of the island, was taken by Hesperon's looks. She regretted what she had done and took the evil spirit from the dragon so that now he would not harm the people of the island but protect them from intruders. Hesperon would catch an intruder but do him no further harm unless the people of the island signalled that they did not recognize the intruder as friendly. Then only would Hesperon devour the intruder.

We find the myth of the dragon Hesperon reflected in our present understanding of how the immune system distinguishes self (native) from non-self (intruder).
Knowledge of how the immune system is kept from turning against itself has allowed the induction of specific tolerance even towards transplanted tissue. This Highlight summarizes the pertinent molecular mechanisms involved in the discrimination of self and non-self by the immune system and outlines exciting new studies in transplant tolerance.

Until the mid-1960s it was thought that the immune system discriminated between self molecules and those belonging to pathogens by deleting all self-reactive lymphocytes early in life, and by retaining only those specific for foreign substances. Then it was discovered that B-cells, once activated, undergo waves of hypermutation, to generate not only B-cell mutants with enhanced recognition of the pathogen, but also rare B-cells which are able to recognize self molecules. Yet how could self-tolerance be maintained in the face of such hypermutation? As mutations generating autoreactive lymphocytes would be fairly rare and two mutations leading to autoreactivity against the same (self) antigen would be even rarer, an immune response should only occur if different cells were to recognize the same antigen at the same time. Bretscher and Cohn (1) set forth a hypothesis that the B-cell is under the control of different signals. It receives Signal one (the death signal, intruder on the island) when its antigen-specific receptor engages the antigen and Signal two (the help signal, intruder not recognized as friendly) from a helper T-lymphocyte that has seen the same antigen. Thus, upon receiving the help signal, an antigenengaged B-cell would divide and make antibody, but if no help signal is received, the B-cell would die, eliminating autoreactive mutants. We know that helper T-cells exist, and that the essential help signal is delivered by a membrane-membrane interaction via the cluster of differentiation (CD) 154 (also called CD40ligand) on the helper T-cell surface and through CD40 on the B-cell surface (2).

B-cells are not the only dangerous immune cells. There are also the killer T-cells which normally clear virus-infected cells and reject transplants, that must refrain from attacking self-tissues. In the late 1980s, it became apparent that most killer T-cells, like B-cells, need to receive the help signal and remain tolerant if they recognize antigen in the absence of the help signal 
(3). This help signal is mediated by CD154 from dendritic cells (one of the antigen-presenting cells) (4). Thus killer T-cells and B-cells follow similar rules. When they receive Signal one without Signal two they are harmless, and they differentiate to make immune responses only if they receive both signals. Thus, CD154 is analogous to the signal telling Hesperon to attack, and blocking the signal would keep Hesperon from being aggressive.

Obviously, it would be possible to block an immune response by blocking either Signal one or two. Without Signal one neither the B- nor T-cell can be activated, and without Signal two, both cell types die when they engage antigen. But blocking of Signal one is not the same as blocking of Signal two. Currently used immunosuppressive drugs in transplantation are glucocorticoids (5), antiproliferative agents (azathioprin, mycophenolate mofetil) (6) and calcineurin inhibitors (cyclosporin A, tacrolimus) (7). The latter block Signal one by blocking calcium fluxes (calcineurin inhibitors) resulting from the interaction of T- or B-cells with their cognate antigens, but the inactivated T-cells continue to circulate, 'blind' to the presence of their antigen. As soon as the 'blindfold' disappears, the reactive cells can recognize the graft (7). The body's normal tolerance mechanism hinges on Signal two, not Signal one. A graft transplanted under the cover of Signal two blockers would be protected by this normal tolerance mechanism, and the reactive cells that recognize the graft should die as a result of not receiving the CD154 signal. Once they are dead, and the graft has healed, it should be possible to stop giving the blockers without producing graft rejection.

In 1996 long-term acceptance of skin and cardiac allografts after blocking CD40 and CD28 pathways (both Signal two) was first reported (8). This concept has now been successfully applied in kidney and pancreatic islet transplantation studies in primates. An extensive study has been performed with the kidney transplant model in rhesus monkeys. Kirk et al. (9) have shown that monkeys given a short course of Signal two blockers accept fully mismatched kidneys with no rejection episodes during the treatment and no signs of rejection when the blockers are withdrawn. Even with strongly mismatched transplantation combinations none of the recipients treated with anti-CD154 rejected the transplants. In vitro studies showed that the monkeys had slowly become tolerant to graft-specific antigens, but were capable of mounting immune responses to other foreign antigens. Further, they reasoned that if recognition of the graft (Signal one) in the absence of Signal two was the mechanism for antiCD154-mediated tolerance induction, then preventing Signal one should prevent tolerance. Indeed, this was the case. If they gave tacrolimus or long-term steroids along with the antibody against CD154 half of the monkeys rejected their grafts, showing that more, in this case, is not better (9).
The same concepts of transplant tolerance apply for pancreatic islet transplantation. Two recent studies in rhesus monkeys (10) and baboons (11) show promising effects of recombinant anti-CD154 antibody infusions after islet transplantation in pancreatectomized animals. Infusions of anti-CD154 in the first weeks after transplantation led to a long-term (up to $>476$ days) survival of functional islet grafts in all animals. In some animals that later showed evidence of graft failure, additional infusions of anti-CD154 were followed by restored islet function as assessed by glucose tolerance tests (11). Six of six transplanted rhesus monkeys became insulin independent for more than 1 year (10). After monthly infusions of anti-CD154 for 1 year, three animals, which no longer received treatment, continued to exhibit adequate islet function.

Moreover, in contrast to conventional immunosuppressive drugs (steroids, cyclosporin A, tacrolimus) which are known to impair normal islet function (12), increase susceptibility to infection and malignancy, stunt normal growth and development, and result in direct organ toxicity, anti-CD154 infusions theoretically should not have these adverse effects. Indeed, in the rhesus monkeys with islet transplants, an improved first phase insulin release in response to intravenous glucose was observed after the first 100 days post transplant $(10,11)$. Side effects of anti-CD154 treatment as assessed by regular physical examinations, blood count and serum chemistries were not found. Some animals showed a transient increase in liver enzymes in the immediate post-transplant period $(10,11)$.

These studies are just the beginning, and many issues arising from the phenomena observed in the grafted monkeys need further clarification. For example, continued production of low levels of anti-donor antibody, tolerance induction towards passenger infectious agents engrafted at the time of transplantation, and histological evidence for infiltration of transplanted kidneys and islets by lymphocytes that might eventually become a problem $(9,11)$. Nevertheless, these studies indicate that by mimicking the body's own tolerance mechanisms towards self, induction of tolerance specifically to transplanted tissues may soon open up the possibility of a cure for type 1 diabetes mellitus.

\section{Acknowledgements}

This work is dedicated to children with diabetes to give them hope. M A H is a recipient of a Juvenile Diabetes Foundation International Career Development Award. I thank Octavia N Devon for help with Greek mythology.

\section{References}

1 Bretscher P \& Cohn M. A theory of self-nonself discrimination. Science $19701691042-1049$. 
2 Saeland S, Duvert V, Moreau I \& Banchereau J. Human B cell precursors proliferate and express CD23 after CD40 ligation. Journal of Experimental Medicine 1993 178 113-120.

3 Guerder S \& Matzinger P. A fail-safe mechanism for maintaining self-tolerance. Journal of Experimental Medicine 1992176553 564.

4 Ridge JP, Di Rosa F \& Matzinger P. A conditioned dendritic cell can be a temporal bridge between a CD4+ T-helper and a T-killer cell Nature $1998393474-478$.

5 Auphan N, DiDonato JA, Rosette C. Helmberg A \& Karin M. Immunosuppression by glucocorticoids: inhibition of NF-kappa B activity through induction of I kappa B synthesis Science 1995 $270286-290$.

6 Platz KP, Bechstein WO, Eckhoff DE, Suzuki Y \& Sollinger HW. RS61443 reverses acute allograft rejection in dogs. Surgery 1991 110 736-740; discussion 740-741.

7 Fruman DA, Klee CB, Bierer BE \& Burakoff SJ. Calcineurin phosphatase activity in T lymphocytes is inhibited by FK 506 and cyclosporin A. Proceedings of the National Academy of Sciences of the USA $1992893686-3690$.
8 Larsen CP, Elwood ET, Alexander DZ, Ritchie SC, Hendrix R, Tucker-Burden et al. Long-term acceptance of skin and cardiac allografts after blocking CD40 and CD28 pathways. Nature 1996 381 434-438.

9 Kirk AD, Burkly LC, Batty DS, Baumgartner RE, Berning JD, Buchanen $\mathrm{K}$ et al. Treatment with humanized monoclonal antibody against CD154 prevents acute renal allograft rejection in nonhuman primates. Nature Medicine 19995 686-693.

10 Kenyon NS, Chatzipetrou M, Masetti M, Ranuncoli A, Oliveira M, Wagner JL et al. Long-term survival and function of intrahepatic islet allografts in rhesus monkeys treated with humanized antiCD154. Proceedings of the National Academy of Sciences of the USA $1999968132-8137$.

11 Kenyon NS, Fernandez LA, Lehmann R, Masetti M, Ranuncoli A, Chatzipetrou $\mathrm{M}$ et al. Long-term survival and function of intrahepatic islet allografts in baboons treated with humanized anti-CD154. Diabetes 199948 1473-1481.

12 Jindal RM, Sidner RA \& Milgrom ML. Post-transplant diabetes mellitus. The role of immunosuppression. Drug Safety 199716 242-257. 